\title{
The Value Evaluation System of Tourism Resources based on Information Processing Technology
}

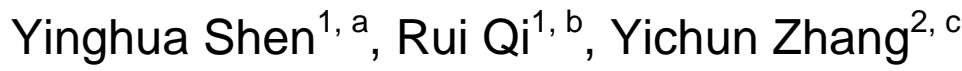 \\ ${ }^{1}$ School of Information Engineering, Communication University of China, Beijing, China \\ ${ }^{2}$ Art Research Institute of China, Beijing, China \\ ashenwan@cuc.edu.cn, b196855140@qq.com, czhangyichun@cuc.edu.cn
}

Keywords: cultural resources, value system, evaluation factors, index weight value, pricing model.

\begin{abstract}
About culture, it has a very broad definition, with its unique ideology, the value evaluation system of physical goods cannot be applied on it, which effects its currency. This paper studied the culture from its value, tried to know the distribution of culture, using AHP (Analytic Hierarchy Process), Fuzzy Comprehensive Evaluation Method or any other methods to make sure the weights of the evaluation factors. At last, got a reasonable value evaluation system of cultural resources, and chose one example to test if it's right.
\end{abstract}

\section{Introduction}

The value of cultural resources is difficult to be evaluated. Currently there has no direct system model about the evaluation of cultural resources at home and abroad. Cultural resources for any field you want to enter the circulation of commodities, the value must have an accurate assessment and measurement. Therefore, the exploration of the value system of cultural resources is necessary and has great significance.

According to different features of cultural resources, this paper is mainly to discuss the pricing of tourism cultural resources and used the following process to explore, shown in Fig. 1:

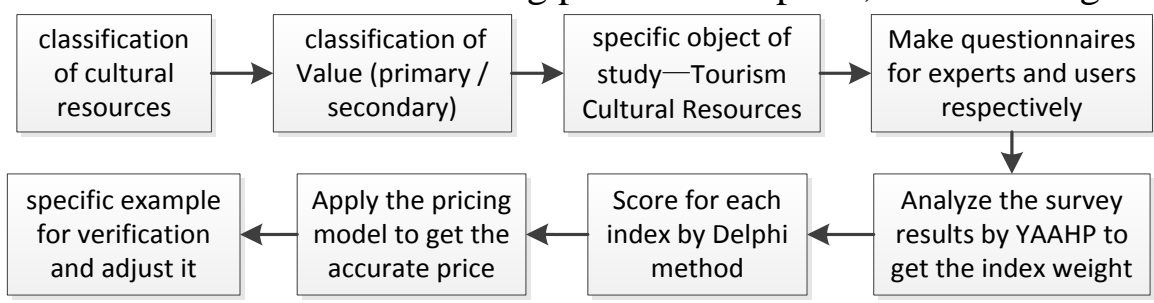

Fig. 1: The Research Flowchart of this paper

\section{Classification of Cultural Resources and Value}

Currently, there are sociologists define culture as the complex of science, technology, learning style, beliefs, knowledge, arts, law and other factors from the ethnological point of view[1]. In the early 1970, the U.S. National Park Service proposed "cultural resources"[2]. Define the field of culture and value involved are basically the same, that "culture and values have interacted relationship."[3]

Classification of Cultural Resources. Culture can be divided into seven categories: [4]

a) Dynamic Arts Culture: opera, dance, crosstalk and other performance arts.

b) Artifacts Culture: antiquities, ceramics, sculptures, etc.

c) History Culture: classics, artifacts, paintings and other ancient cultures.

d) Folk Culture: folk snacks, local customs and other ethnic cultures.

e) Tourism Culture: scenic, historical sites, tourist attractions, such as national or local level.

f) Religion Culture: religious classics and buildings, religious beliefs, etc.

g) Book Culture. 
Classification of Value. Value is complex and has diverse forms. It can be classified according to its different specific characteristics. This paper divided the value index into primary index and secondary index from the cultural value.

The Primary Index of Cultural Resources: Economy Value $\left(\mathrm{Y}_{1}\right)$, Appreciation Value $\left(\mathrm{Y}_{2}\right)$, IT Value $\left(\mathrm{Y}_{3}\right)$, Cultural Heritage Value $\left(\mathrm{Y}_{4}\right)$, Politic Value $\left(\mathrm{Y}_{5}\right)$, Existence Value $\left(\mathrm{Y}_{6}\right)$, Geography Value $\left(\mathrm{Y}_{7}\right)$, Education Value $\left(\mathrm{Y}_{8}\right)$, Spirit Value $\left(\mathrm{Y}_{9}\right)$, History Value $\left(\mathrm{Y}_{10}\right)$. [5]

The Secondary Index of Cultural Resources: Commodity $\left(\mathrm{P}_{1}\right)$, Actual Function $\left(\mathrm{P}_{2}\right)$, Artistry $\left(\mathrm{P}_{3}\right)$, Aesthetics $\left(\mathrm{P}_{4}\right)$, Technical Content $\left(\mathrm{P}_{5}\right)$, Production Means $\left(\mathrm{P}_{6}\right)$, Retentively $\left(\mathrm{P}_{7}\right)$, Continuity $\left(\mathrm{P}_{8}\right)$, Pioneer $\left(\mathrm{P}_{9}\right)$, Authority $\left(\mathrm{P}_{10}\right)$, Scale $\left(\mathrm{P}_{11}\right)$, Authenticity $\left(\mathrm{P}_{12}\right)$, Integrity $\left(\mathrm{P}_{13}\right)$, Region $\left(\mathrm{P}_{14}\right)$, Influence $\left(\mathrm{P}_{15}\right)$, Education Meaning $\left(\mathrm{P}_{16}\right)$, Ethnic Identity $\left(\mathrm{P}_{17}\right)$, Commemorative $\left(\mathrm{P}_{18}\right)$, Time Span $\left(\mathrm{P}_{19}\right)$, Rarity $\left(\mathrm{P}_{20}\right)$.

\section{Value System’s pricing Model and Evaluation Methods of Cultural Resources}

Value System of Cultural Resources. The value index of cultural resources can be divided into the primary index and secondary index and there are some relations between them. Specific weight of each index should be based on the classification of specific cultural resources. Shown in Fig. 2:

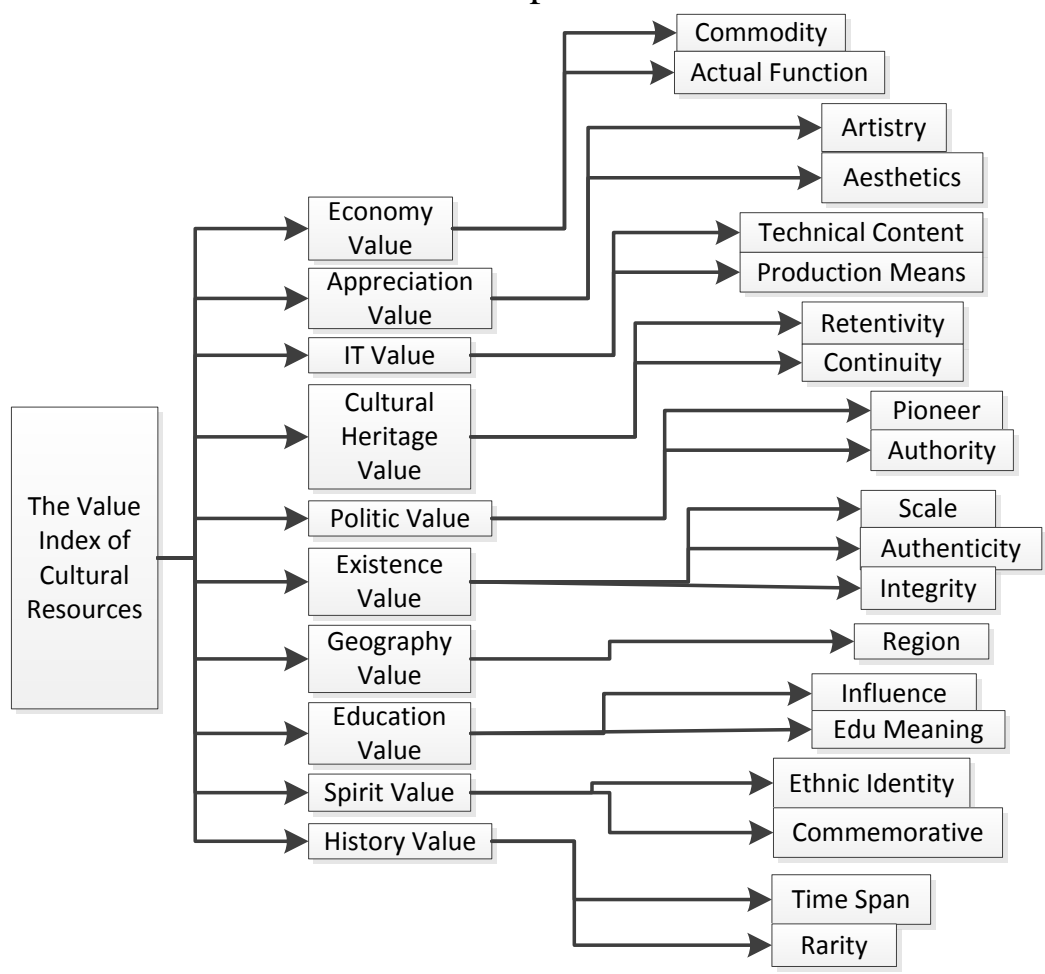

Fig. 2: The Value System of Cultural Resources

Pricing Model of Cultural Resources. According to the value system, this paper gives the pricing model [6] of cultural resources, shown as follows:

$$
P=A^{*} \sum_{j=1}^{20} X_{i} P_{j} \text {. }
$$

$\mathrm{P}$ is the price of the specific resource; $\mathrm{Xi}$ is the variable, $\mathrm{i}=1,2,3,4$; $\mathrm{Pj}$ is the weight, $\mathrm{j}=$ $1,2 \ldots . .19,20$; $\mathrm{A}$ is a constant, means price.

There is a method to calculate A. Design a questionnaire for the middle-income families to survey the ideal price of users (such as 500 copies), then we can know the price range of this cultural resource. For example, the price range is from a1 to a2, its middle is (a1+a2)/2, and the middle of 1 to 4 is 2.5 , so the price formula is $A=(a 1+a 2) /(2 * 2.5)$ [7].

After knowing the specific cultural resource and its evaluation factors, we can get the specific price. 
Evaluation Methods. The evaluation methods of this paper are: Analytic Hierarchy Process [8] (AHP), Delphi Method [9], Fuzzy Comprehensive Evaluation Method [10] and User Survey Method.

In summary, to begin with get variables by Delphi method. Secondly, calculate the weight of each index by AHP. Thirdly, analyze the result by Fuzzy Comprehensive Evaluation method. Finally, get the value system of tourism cultural resources.

\section{Case Study}

\section{Value Evaluation of Tourism Cultural Resources.}

1) Definition of Tourism Cultural Resources

Tourism includes the natural landscape and cultural landscape, and tourism culture can be divided into tourism material culture, tourism spirit culture and tourism norm culture. If tourism culture is a big system, then tourism material culture is the surface layer, tourism norm culture is the middle layer, and tourism spirit culture is the deepest layer, which is the chore of the system and determines the basic features and characteristics of a specific kind of tourism culture[11].

2) Value System of Tourism Cultural Resources

According to the value system of cultural resources, this paper gives the value system of tourism cultural resources [12], shown in Table 1 which was shown later.

Each index weight in the table is calculated as follows:

a) User Survey Method: Analyzing the feedbacks of users’ questionnaires (508 copies).

b) Delphi Method: Scoring variables and sorting the primary indexes of tourism cultural resources according to their degree of importance.

Appreciation Value $>$ Cultural Heritage Value $>$ History Value $>$ Education Value $>$ Existence Value $>$ Spirit Value $>$ Economy Value $>$ Geography Value $>$ IT Value $>$ Politic Value

The important degree on price is: 9 (Very Important); 7 (Quite Important); 5 (A Little Important); 3 (Not So Important); 1 (Not Important).

Given the result as follows:

9: Appreciation Value

7: Cultural Heritage Value, History Value, Education Value

5: Existence Value, Spirit Value, Economy Value

3: Geography Value

1: IT Value, Politic Value

c) AHP: Taking the result above into YAAHP to analysis and calculate the weight of each index. Shown as Fig. 3 and 4.

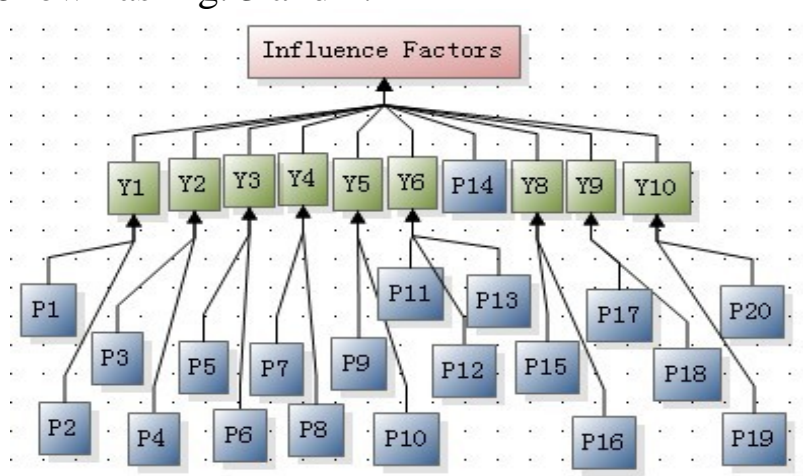

Fig. 3: Hierarchical Model

\begin{tabular}{|c|c|c|c|c|c|c|c|c|c|}
\hline Y1 & Y2 & Y3 & Y4 & Y5 & Y6 & Y8 & Ү९ & Y10 & P14 \\
\hline Y1 & $1 / 5$ & 5 & $1 / 3$ & 5 & $1 / 2$ & 3 & $1 / 3$ & $1 / 2$ & $1 / 3$ \\
\hline I2 & & 9 & $1 / 3$ & 9 & 5 & 7 & 3 & 5 & 3 \\
\hline Y3 & & & $1 / 7$ & 2 & $1 / 5$ & $1 / 3$ & $1 / 7$ & $1 / 5$ & $1 / 7$ \\
\hline Y4 & & & & 7 & 3 & 5 & 2 & 3 & 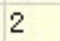 \\
\hline Y5 & & & & & $1 / 5$ & $1 / 3$ & $1 / 7$ & $1 / 5$ & $1 / 7$ \\
\hline Y6 & & & & & & 3 & $1 / 3$ & 2 & $1 / 3$ \\
\hline Y8 & & & & & & & $1 / 5$ & $1 / 3$ & $1 / 5$ \\
\hline Y9 & & & & & & & & 3 & $1 / 2$ \\
\hline Y10 & & & & & & & & & $1 / 3$ \\
\hline P14 & & & & & & & & & \\
\hline
\end{tabular}

Fig. 4: Judgment Matrix of Value

\section{Example of Scenic Pricing System - Tianjin Qilihai National Wetland Park.}

1) Brief Introduction about Qilihai National Wetland Park

Qilihai is a national conservation area which was proved by the State Council and it's the national 4A level scenic spot. The scenic is equipped with wetland corridor up to $8 \mathrm{~km}$ and 6,000 acres of the original wetland, and there are aquatic display area, bird watching station, duck pond, Swan Lake, carp pond, crab fishing pond, catering cabins, a central fountain stage, Rose Hall, wedding 
photography base, barbecue garden, hydrophilic corridor, children's park, fairy tale castle, field training area, and many other tours. Meanwhile you can also take the cable car to watch the beautiful wetland corridor and take a luxury Chinese boat floating in acres of reeds.

2) Value System of Qilihai National Wetland Park

According to the features of Qilihai, this paper gives the value system of Qilihai National Wetland Park, shown in bold font in Table 1. In addition, the ticket price of Qilihai is 120 yuan, this paper would evaluate it by the evaluation system just talk about.

3) Pricing of Qilihai National Wetland Park

This paper assesses the value of Qilihai National Wetland Park through the data, shown in bold font in Table 1 and combines them to the formula (1).

Issuing questionnaires (100 copies) to users to know that people's willingness to pay for Qilihai is $60-120$ yuan. So $\mathrm{A}$ is:

$$
A=(60+120) /(2 * 2.5)=36(\text { yuan }) \text {. }
$$

The price of the park is given as follows:

$$
P=36 * 2.9374=105.75 \text { (yuan) }
$$

The result is close to the actual price of Qilihai-120 yuan, verifying that the hypothesis is established.

\begin{tabular}{|c|c|c|c|c|c|c|}
\hline \multicolumn{2}{|c|}{ Influence Factors } & Weight $\left(\mathrm{P}_{\mathrm{j}}\right)$ & $4\left(X_{1}\right)$ & $3\left(X_{2}\right)$ & $2\left(X_{3}\right)$ & $1\left(\mathrm{X}_{4}\right)$ \\
\hline \multirow{2}{*}{$\begin{array}{c}\text { Economy } \\
\text { Value }\left(\mathrm{Y}_{1}\right) \\
0.0430\end{array}$} & $\begin{array}{c}\text { Commodity } \\
\left(\mathrm{P}_{1}\right) \\
(\text { Tourism } \\
\text { Income/GDP) }\end{array}$ & 0.0191 & $\begin{array}{c}{[6.5 \%,} \\
7.5 \%]\end{array}$ & $\begin{array}{c}\text { [10.5\% } \\
16.5 \%]\end{array}$ & $(7.5 \%, 10.5 \%)$ & 0.0191 \\
\hline & $\begin{array}{c}\text { Actual } \\
\text { Function }\left(\mathrm{P}_{2}\right)\end{array}$ & 0.0382 & $\begin{array}{l}\text { Leisure } \\
\text { Resort }\end{array}$ & $\begin{array}{l}\text { Artificial } \\
\text { Landscape }\end{array}$ & $\begin{array}{l}\text { Historical } \\
\text { Landscape }\end{array}$ & $\begin{array}{c}\text { Natural } \\
\text { Landscape }\end{array}$ \\
\hline \multirow{2}{*}{$\begin{array}{c}\text { Appreciation } \\
\text { Value }\left(\mathrm{Y}_{2}\right) \\
0.2819\end{array}$} & Artistry $\left(\mathrm{P}_{3}\right)$ & 0.1586 & $\begin{array}{c}\text { Top } \\
\text { well-known } \\
\text { Art Exhibits }\end{array}$ & $\begin{array}{l}\text { well-known } \\
\text { Art Exhibits }\end{array}$ & $\begin{array}{l}\text { Ordinary Art } \\
\text { Exhibits }\end{array}$ & $\begin{array}{l}\text { Have no Art } \\
\text { Exhibits }\end{array}$ \\
\hline & $\begin{array}{l}\text { Aesthetics } \\
(\mathrm{P} 4)\end{array}$ & 0.0793 & Top Value & High Value & General Value & $\begin{array}{l}\text { Have no } \\
\text { Value }\end{array}$ \\
\hline \multirow{2}{*}{$\begin{array}{c}\text { IT Value } \\
\left(\mathrm{Y}_{3}\right) \\
0.0181\end{array}$} & $\begin{array}{c}\text { Technical } \\
\text { Content }\left(\mathrm{P}_{5}\right)\end{array}$ & 0.0139 & High Tech & General Tech & Low Tech & Do not need \\
\hline & $\begin{array}{l}\text { Production } \\
\text { Means }\left(\mathrm{P}_{6}\right)\end{array}$ & 0.0046 & Very hard & A little hard & Quite easy & Very easy \\
\hline \multirow{2}{*}{$\begin{array}{c}\text { Cultural } \\
\text { Heritage } \\
\text { Value }\left(\mathrm{Y}_{4}\right) \\
0.0673\end{array}$} & $\begin{array}{l}\text { Retentivity } \\
\qquad\left(\mathrm{P}_{7}\right)\end{array}$ & \multirow{2}{*}{0.2155} & \multirow{2}{*}{$\begin{array}{c}\text { Worthy of } \\
\text { permanent } \\
\text { retention and } \\
\text { continuation }\end{array}$} & \multirow{2}{*}{$\begin{array}{l}\text { Can be } \\
\text { retained and } \\
\text { continued } \\
\text { quite long }\end{array}$} & \multirow{2}{*}{$\begin{array}{l}\text { Can be retained } \\
\text { and continued } \\
\text { for a short time }\end{array}$} & \multirow{2}{*}{ One-time } \\
\hline & $\begin{array}{l}\text { Continuity } \\
\qquad\left(\mathrm{P}_{8}\right)\end{array}$ & & & & & \\
\hline $\begin{array}{c}\text { Politic Value } \\
\left(\mathrm{Y}_{5}\right) \\
0.0242\end{array}$ & Pioneer $\left(\mathrm{P}_{9}\right)$ & 0.0107 & The first one & $\begin{array}{l}\text { Later but } \\
\text { more } \\
\text { prominent }\end{array}$ & $\begin{array}{l}\text { Earlier but } \\
\text { more normal }\end{array}$ & $\begin{array}{c}\text { Later and } \\
\text { very normal }\end{array}$ \\
\hline
\end{tabular}

Table 1: The Value System of Tourism Cultural Resources 


\begin{tabular}{|c|c|c|c|c|c|c|c|}
\hline & $\begin{array}{c}\text { Authority } \\
\left(\mathrm{P}_{10}\right)\end{array}$ & \multicolumn{2}{|c|}{0.0054} & $\begin{array}{l}\text { Private-led } \\
\text { private } \\
\text { sector }\end{array}$ & $\begin{array}{l}\text { State-owned } \\
\text { enterprises } \\
\text { led }\end{array}$ & $\begin{array}{c}\text { Local } \\
\text { government-led }\end{array}$ & State-owned \\
\hline \multirow{3}{*}{$\begin{array}{c}\text { Existence } \\
\text { Value }\left(\mathrm{Y}_{6}\right) \\
0.0995\end{array}$} & Scale $\left(\mathrm{P}_{11}\right)$ & \multicolumn{2}{|c|}{0.0189} & Aggregation, & centralization & Dispersion & Single \\
\hline & $\begin{array}{l}\text { Authenticity } \\
\qquad\left(\mathrm{P}_{12}\right)\end{array}$ & \multicolumn{2}{|c|}{0.0378} & $\begin{array}{c}\text { Real History } \\
\text { Exhibits }\end{array}$ & $\begin{array}{l}\text { Fake Tech } \\
\text { Exhibits }\end{array}$ & $\begin{array}{l}\text { Fake Manual } \\
\text { Exhibits }\end{array}$ & $\begin{array}{l}\text { Shoddy } \\
\text { Exhibits }\end{array}$ \\
\hline & Integrity $\left(\mathrm{P}_{13}\right)$ & \multicolumn{2}{|c|}{0.0189} & $\begin{array}{c}\text { Complete } \\
\text { and Valuable }\end{array}$ & $\begin{array}{l}\text { Incomplete } \\
\text { but Valuable }\end{array}$ & $\begin{array}{c}\text { Complete but } \\
\text { Cheap }\end{array}$ & $\begin{array}{l}\text { Incomplete } \\
\text { and Cheap }\end{array}$ \\
\hline $\begin{array}{l}\text { Geography } \\
\text { Value }\left(\mathrm{Y}_{7}\right)\end{array}$ & Region $\left(\mathrm{P}_{14}\right)$ & \multicolumn{2}{|c|}{0.0317} & $\begin{array}{l}\text { First-tier } \\
\text { Cities }\end{array}$ & $\begin{array}{l}\text { Second-tier } \\
\text { Cities }\end{array}$ & $\begin{array}{l}\text { Third-tier } \\
\text { Cities and } \\
\text { Suburbs }\end{array}$ & Rural areas \\
\hline \multirow{2}{*}{$\begin{array}{c}\text { Education } \\
\text { Value }\left(\mathrm{Y}_{8}\right) \\
0.0995\end{array}$} & $\begin{array}{l}\text { Influence } \\
\left(\mathrm{P}_{15}\right)\end{array}$ & \multicolumn{2}{|c|}{0.0874} & Huge & Big & Small & Tiny \\
\hline & $\begin{array}{l}\text { Education } \\
\qquad\left(\mathrm{P}_{16}\right)\end{array}$ & \multicolumn{2}{|c|}{0.0437} & Huge & Big & Small & Tiny \\
\hline \multirow{2}{*}{$\begin{array}{c}\text { Spirit Value } \\
\text { (Y9) } \\
0.1522\end{array}$} & $\begin{array}{c}\text { Ethnic } \\
\text { Identity }\left(\mathrm{P}_{17}\right)\end{array}$ & \multicolumn{2}{|c|}{0.0438} & $\begin{array}{c}\text { World } \\
\text { Heritage, } \\
\text { National } \\
\text { Resources }\end{array}$ & $\begin{array}{l}\text { Provincial } \\
\text { Resources }\end{array}$ & $\begin{array}{l}\text { Municipal } \\
\text { resources }\end{array}$ & $\begin{array}{c}\text { Personal } \\
\text { Resources }\end{array}$ \\
\hline & $\begin{array}{l}\text { Commemorative } \\
\left(\mathrm{P}_{18}\right)\end{array}$ & \multicolumn{2}{|c|}{0.0219} & Huge & Big & Small & Tiny \\
\hline \multirow{5}{*}{$\begin{array}{c}\text { History } \\
\text { Value }\left(\mathrm{Y}_{10}\right) \\
0.1738\end{array}$} & $\begin{array}{l}\text { Time Span } \\
\qquad\left(\mathrm{P}_{19}\right)\end{array}$ & \multicolumn{2}{|c|}{0.1004} & $\begin{array}{l}\text { Yuan, Ming, } \\
\text { Qing }\end{array}$ & $\begin{array}{c}\text { Communist } \\
\text { era }\end{array}$ & $\begin{array}{l}\text { Beginning of } \\
\text { the } 21 \text { st century }\end{array}$ & Currently \\
\hline & \multirow{4}{*}{$\begin{array}{l}\text { Rarity }\left(\mathrm{P}_{20}\right) \\
\text { (Numbers of } \\
\text { similar } \\
\text { attractions.) }\end{array}$} & \multirow{4}{*}{$\begin{array}{l}0.050 \\
2\end{array}$} & $\begin{array}{c}4 / 5 \\
\mathrm{~A} \\
\end{array}$ & 1 & $2-3$ & $4-5$ & 6 or more \\
\hline & & & $3 \mathrm{~A}$ & $1-5$ & $6-10$ & $10-25$ & 25 or more \\
\hline & & & $2 \mathrm{~A}$ & $1-5$ & $6-10$ & $10-25$ & 25 or more \\
\hline & & & $1 \mathrm{~A}$ & 1 & 2 & 3 & 3 or more \\
\hline
\end{tabular}

\section{Conclusion}

The example mentioned above is mainly to build the value evaluation system according to the content of cultural resources. However, there are still some problems in the research. In a word, recognized evaluation system is hard to determine, if want to get a perfect value evaluation system, there is still a long way to go. We should continue to improve it through comparative analysis and apply it on more actual examples until get the most accurate result and closest to the actual value system. 


\section{Summary}

This paper gave a more complete classification about cultural resources and value, and made much expansion on the basis of some experts to assess the value of cultural resources more comprehensive so that got a more perfect and accurate value system. In addition, this essay selected tourism cultural resources as the example to research and improved its original value index to get a more reasonable pricing system. Finally, the value system was applied on a specific scenic.

However, the value system still has some drawbacks. Culture cannot be divided so accurate and the value of culture is too complicated to be considered. Furthermore, all evaluation methods are a little subjective. To sum up, in the future will take more researches to validate so that get a perfect value evaluation system that is applicable to all kinds of cultural resources.

\section{Acknowledgment}

This work is supported by two projects of Nation Science and Technology, one of the subjects is: The research of the parallel and mutually beneficial operating mode of digital cultural resources for public service and commercial operations (2012BAH01F01-01), and another one is : Based on public cultural dissemination of new triple play model research and demonstration(WHB1002).

\section{References}

[1] Ke Guo Tu. The Value Analysis of Culture [J]. History and Philosophy, 1992 No.3

[2] Fowler. Cultural Resources Manage.ent [A].in Schifrer, M. B. ed. Advances in Archaeologocal Method and Theory[M].Vol.5,Ne.York:AeademiePress.1982:1

[3] Ming Yu Huang. Value Evaluation and Record of Cultural Heritage [J]. Fudan University, 2009 Vol.4 No.13

[4] Fu Zhong Su. Distribution System of Culture [J]. Journal of Yantai University. 2004.7 Vol.17 No.3

[5] Jie Zhang. The Research of Digital Resources Long-term Preservation Comprehensive Evaluation Method [J]. Northeast Normal University, 2010.5

[6] Xiao Liu. Discussion about Tickets Prices of Attractions [J]. Tourism Tribune, 2005, No.3

[7] Run De Lu, Xi Mei Liu, Min Rui Song, Li Jun Pan. Pricing Model of National Attractions [J]. Tourism Tribune, 2008, No.11

[8] Xiao Chun Zhang. Study on Cultural Resources [J]. Enterprise Science and Technology \& Development, 2008 No.12

[9] Yu Mei Cheng. Domestic Digital Resources Evaluation System Research [J]. New Century Library, 2007 No.6

[10]Xiang Lin Deng, Ya Zhao Chen. Digital Resources Evaluation Model of University’s Library Based on Fuzzy Comprehensive Evaluation Method [J]. Contemporary educational theory and practice, 2009, Vol.6 No.20

[11]Ai Ping Liu. Discussion about the Value of Tourism and Culture [J]. Tourism Forum, 2009.8, Vol.2 No.4

[12] Xiao Ting Huang. Study on Tickets Pricing Factors of National Attractions [J]. Tourism Tribune, 2007, No.5 